\title{
China's Anti-Corruption Legislation: A Review of the Supervision Law from the Perspective of Human Rights Protection
}

\section{Yuan Chufeng*}

China's Supervision Law is the legislation that governs China's leading and fundamental approach to anti-corruption. Its main content includes the objective, guiding ideology, principle and leadership system of supervision work, the authority, formation and duties of the supervision committee, the supervision procedures, and the supervision of the supervisory organizations and supervisors. The Supervision Law embodies the characteristics of a combination of party rules and national laws. This power structure is completely different from the separation of powers in Western countries: it does not control power by checks and balances and civil rights. This raises concerns about "who will supervise the power of the Commission or a higher level of power," "human rights protection" and "procedural issues." The Supervision Law not only means significant changes in China's anti-corruption legislation, but also those in China's governance style, which will have a profound impact on China's future political and legal aspects.

Keywords: Anti-corruption, Supervision Law, Supervisory Committee, Dual Duties, Two Regulations, Criminal Procedure Law

* Senior lecturer at the School of Literature and Law at East China University of Technology. Ph.D. in Law (S.W. Univ./U.C. Dublin). ORCID: http://orcid.org/0000-0003-4115-8472. The author may be contacted at: yuanchufeng@163.com/Address: East China University of Technology, 418 Guanglan Avenue, Changbei Jingkai District, Nanchang, P.R. China 330013. All the websites cited in this article were last visited on August 3, 2019. 


\section{INTRODUCTION}

The effectiveness of corruption control is part of the important criteria for measuring the modernity of a country. Modern countries have actively established more effective corruption governance systems. In 2012, the 18th National Congress of the Communist Party of China "clearly put forward new goals and requirements for a sound legal system and scientific and effective governance of corruption." A series of reform of the country's political system - an improvement in the power supervision system, the establishment of the rule of law in the operation of power, and a modernization of state governance - is the only way to curb the corruption. In 2017, the 19th National Congress of the Communist Party of China further clarified that there is a need to "deepen the symptoms and root causes and ensure that the cadres are correct, the government is honest, and politically clear" and "strengthen restrictions and supervision on the operation of power and put power under the control of the system.," This marks China's entering into a new period of struggling against corruption. Focusing on the structural renewal of the corruption supervision system, China has opened up the "second battlefield" of national corruption governance legislation; promoted the transformation of the state's corruption governance from 'resulting' to 'portal' and process governance; and improved the ability of the country to control corruption. These have been the principal contents of anti-corruption legislation in the latest corruption governance in China. ${ }^{3}$

The outstanding problems of China's original supervision system are as follows: 1) the scope of supervision is too narrow; 2) anti-corruption forces are scattered; and 3) the specific duties are not enough centralized. After the reform of China's monitoring system, the following were established: 1) supervision objective as to achieve full coverage of all public officials exercising public power; 2) integration of forces such as administrative supervision departments, corruption prevention agencies and procuratorial organizations investigating corruption and bribery, dereliction of duty, and prevention of duty crimes; 3 ) the supervisory committees at all levels as the specialized agencies that exercise the functions of the state's supervision.

In view of the drawbacks of the traditional corruption governance system, such as decentralized supervision, constricted scope of supervision, and insufficient 
supervisory capabilities, in November 2016, China deployed pilot projects to reform the monitoring system in Beijing, Zhejiang and Shanxi. ${ }^{4}$ As a "major political system reform that has a bearing on the overall situation," the reform of the national monitoring system involved the adjustment of the state power system. The focus was on placing the decentralized supervisory power in the Supervisory Committee and on performing the allocation and operation of its power within the current constitutional framework. Through this approach, a systematic upgrade of the "Chinese Model" of the corruption governance system was achieved. In March 20, 2018, on the basis of summarizing the experience of the reform pilot area, the first meeting of the 13th National People's Congress passed the Supervision Law of the People's Republic of China (hereinafter The Supervision Law: "SLPRC") and established the legal basis for the operation of the supervisory system. ${ }^{5}$

The enactment of the Supervision Law is tantamount to upholding the unity of inner-party supervision and state supervision. Inner-party supervision is the supervision of all party members, especially party cadres. State supervision is the exercise of supervision over all public officials who exercise public power: " $80 \%$ of civil servants and over $95 \%$ of leading cadres are communists in China." not only established the internal consistency of supervision within the party and the state, but also determined the inevitability of the integration of supervision within the party and the supervision of the state. This kind of supervision system that unites the two organically has distinctive Chinese characteristics.

This research will scrutinize the recent developments in China's anti-corruption in the period of Xi Jinping, as mainly reflected by the Supervision Law of the People's Republic of China, through an analysis of Chinese laws and official documents. This paper aims to shed some light on the latest underlying changes in Chinese law and politics. Furthermore, it will strongly propose that China's anti-corruption legislation should be interpreted from multiple perspectives and aspects.

This paper is composed of five parts including Introduction and Conclusion. Part two will discuss the content of the Supervision Law. Part three will present the basic characteristics of the Supervision Law. Part four will highlight the disputes and tasks of the Supervision Law on human rights protection issues and the supervision of power. 


\section{The Content of the Supervision Law}

The Supervision Law consists of nine chapters with 69 articles, including general principles, supervisory authorities and their responsibilities, scope and jurisdiction of supervision, supervisory authority, monitoring procedures, international cooperation against corruption, supervision of supervisory authorities and supervisors, and legal responsibility and supplementary provisions.

\section{A. The Guiding Ideology and Leadership System of Supervision Work}

The Supervision Law was adopted to uphold and strengthen the centralized and unified leadership of the Communist Party of China in anti-corruption work. The leadership of the Communist Party of China in the national supervision work shall be adhered to; Marxism-Leninism, Mao Zedong Thought, Deng Xiaoping Theory, the Theory of Three Represents, the Scientific Outlook on Development, and Xi Jinping Thought on Socialism with Chinese Characteristics for a New Era. In this regards, a centralized, unified, authoritative and efficient national supervision system with Chinese characteristics shall be established. ${ }^{7}$

\section{B. Supervision Principles and Guidelines \\ 1. Principles}

Supervisory commissions shall independently exercise supervisory power in accordance with the law, free from interference by any administrative organization, public organization or individual. Supervisory organizations shall, in handling dutyrelated violations or crimes, cooperate with judicial organizations, procuratorial organizations, and law enforcement organizations, with mutual checks. Where the supervisory organization requires assistance in its work, the relevant organizations and entities shall assist in accordance with the law, depending on the requirements of the supervisory organization. ${ }^{8}$

\section{Guidelines}

The supervisory work of the state shall strictly conform to the constitution and laws; take facts as the basis and laws as the criterion; equally apply laws to all parties; and guarantee the parties' lawful rights and interests. Equal consideration shall be paid to power and responsibility; strict supervision shall be conducted; 
punishment shall be integrated with education; and leniency shall be combined with severity. ${ }^{9}$

\section{Formation and Duties of the Supervisory Committee}

\section{Formation}

The National Supervisory Commission is created by the National People's Congress responsible for the supervision work nationwide. The National Supervisory Commission comprises one chairman, several vice-chairmen, and several members. The chairman is chosen by the National People's Congress and the vice-chairmen, and members are appointed or removed by the Standing Committee of the National People's Congress, as proposed by the Chairman of the National Supervisory Commission. The term of office of the Chairman of the National Supervisory Commission is similar to the term of the National People's Congress. The Chairman of the National Supervisory Commission shall serve no more than two consecutive terms. The National Supervisory Commission is accountable to the National People's Congress and its Standing Committee and accepting their supervision. ${ }^{10}$

Supervisory commissions at various local levels are made by the people's congresses at the corresponding levels and are responsible for the supervision work within their respective administrative regions. Supervisory commissions at various regional levels are composed of one chairman, several vice-chairmen, and several members. The chairman is chosen by the people's congress at the corresponding level. Vice-chairmen and members are appointed or removed by the standing committee of the people's congress at the corresponding level, as proposed by the chairman of the supervisory commission. The term of office of the chairmen of supervisory commissions at various regional levels is as good as that of the people's congresses at the corresponding levels. Supervisory commissions at various regional levels are accountable to the people's congresses at the corresponding levels and their standing committees and to supervisory commissions at the immediate higher levels. They accept their supervision. ${ }^{11}$

\section{Duties}

A supervisory commission shall, in accordance with the provisions of the Supervision Law and relevant laws, perform the duties of supervision, 
investigation and disposition as follows: ${ }^{12}$

1) It shall provide integrity education to public officials and conduct supervision and inspection of municipal officials' performance of functions in accordance with the law, impartial exercise of power, clean administration, and moral integrity. ${ }^{13}$

2) It shall conduct investigations of duty-related violations and crimes such as suspected corruption, bribery, abuse of power, neglect of duty, power rent-seeking, tunneling, practices of favoritism and falsification as well as waste of state assets. ${ }^{14}$

3) It shall, in accordance with the law, make decisions on government sanctions against public officials who violate any law, hold liable leaders who fail to perform their functions in an effective manner or neglect their duties and responsibilities, transfer investigation results on suspected duty-related crimes to people's procuratorates for examination and initiation of a public prosecution in accordance with the law, and offer supervisory suggestions to the entities in which supervisory objects work. ${ }^{15}$

\section{Full Supervision of All Public Officials Exercising Public Power}

Supervisory organizations shall conduct supervision of the following public officials and relevant personnel as follows:

1) Civil servants of organizations of the Communist Party of China, organizations of people's congresses and their standing committees, people's governments, supervisory commissions, people's courts, people's procuratorates, organizations of the Chinese People's Political Consultative Conference (CPPCC) Commissions at all levels, organizations of democratic parties and associations of industry and commerce, and personnel managed, mutatis mutandis, by the Civil Servant Law of the People's Republic of China. ${ }^{16}$

2) Personnel engaged in public affairs of organizations managing public affairs upon authorization by laws or regulations or lawful entrustment by state organizations. ${ }^{17}$

3) Managers of state-owned enterprises. ${ }^{18}$

4) Personnel engaged in management in public entities in education, scientific research, culture, health care, and sport, among others. ${ }^{19}$

5) Personnel engaged in management at basic-level self-governing mass organizations ${ }^{20}$

6) Other personnel who perform public duties in accordance with the law. ${ }^{21}$ 


\section{E. Endowing the Supervisory Organization with the Necessary Authority}

It is stipulated that the supervisory authority may take measures such as interviews, interrogations, inquiries, freezes, searches, retrievals, seizures, inspections and appraisals in the investigation of illegal and duty crime. ${ }^{22}$

Where the person under investigation is suspected of corruption, bribery, neglect of duty, malfeasance in office, or any other serious duty-related violation or duty-related crime and where the supervisory organization has obtained some facts and evidence on the violation or crime but needs to conduct further investigations into important issues, after examination and approval by the supervisory organization in accordance with the law, the person may be detained at a specific place under any of the following circumstances: the person is involved are major or complicated; the person may escape or commit suicide; the person may make a false confession in collusion or forge, conceal or destroy evidence; and/or the person may commit any other conduct that obstructs investigation. The supervisory organization may, in accordance with the provision of the preceding paragraph, detain any person who is suspected of giving bribes or committing any joint duty-related crime. The setup, management and supervision of detention places shall be governed by the relevant provisions of the state. ${ }^{23}$

If the supervisory authority needs to make technical investigations, obtain general information, or restrict exit measures, it shall go through strict approval procedures and submit it to relevant agencies in accordance with regulations. ${ }^{24}$

\section{F. Regulatory Monitoring Procedures}

Strict stipulations are put in place for the supervision, investigation, and disposal of work procedures, including the handling of reports or records; the management and disposal of problem clues; the decision to initiate investigations; procedures such as searches and seizures that require full audio and video recording of interrogation and important evidence collection work. ${ }^{25}$

The following are the procedures for the retention of measure. The adoption of a detention measure by a supervisory organization shall be decided upon collective research by leaders of the supervisory organization. The adoption of a detention measure by a supervisory organization at or below the level of a district city shall be reported to the supervisory organization at the immediate higher level for approval. The provincial supervisory organization that decides to take 
the detention measure shall report it to the National Supervisory Commission for retardation. Detention shall not exceed three months. Under particular circumstances, the supervisory organization may extend the detention once for no more than three months. ${ }^{26}$

If a supervisory organization at or below the provincial level takes the detention measure, the extension shall be reported to the supervisory organization at the immediate higher level for approval. If the supervisory organization finds the detention measure inappropriate, it shall remove the measure in a timely manner. When the supervisory organization takes the detention measure, it may, when its work so requires, request the assistance of the public security organization. The public security organization shall provide assistance in accordance with the law. ${ }^{27}$

After the detention measure is taken against the person under investigation, the entity where the detained person work and his or her family member shall be notified within 24 hours, except under circumstances where evidence may be destroyed or forged, the testimony of a witness may be interfered with, a false confession may be made in collusion, or the investigation may otherwise be affected. After the circumstances that affect the investigation disappear, the entity where the detained person works and his or her family member shall be notified immediately. The supervisory organization shall guarantee the food, drink, rest and security of the detained person and provide medical services. Interrogation time and length shall be reasonably arranged for the interrogation of the detained person. Interrogation records shall be also signed by the interrogated person after their reading. ${ }^{28}$

\section{G. Supervision of Supervisory Organizations and Inspectors}

\section{Supervision of the People's Congress}

The supervisory organizations should accept the supervision of the people's congress and its standing committee at the same level. The standing committee of the people's congress at all levels shall listen to and consider the special work reports of the supervisory organizations at the same level and organize the law enforcement inspection. Also, the people's congresses or their standing committees shall be composed of people at the present level. When holding a meeting, the Congress and its Standing Committee may, in accordance with the procedures prescribed by law, ask questions or inquiries about relevant issues in 
the supervision work. ${ }^{29}$

\section{Strengthening self-supervision}

In line with the Chinese Communist Party's disciplinary inspection authority overseeing the rules of discipline work, effective practices have been actually raised to legal norms. It stipulates the systems for inquiries, cases of interrogation, intervening reports and registration of records, supervision of supervisors, management of desensitizing periods, resignation of supervisors, and restrictions on employment after retirement. At the same time, a system of complaints and accountability for the misconduct of the supervisory authority and its staff is provided. $^{30}$ It also clearly stipulates that supervisory organizations should openly monitor work information according to law and accept democratic supervision, social supervision, and public opinion supervision. ${ }^{31}$

\section{Clear mechanism for mutual coordination and supervision}

If the supervisory organizations of the people's procuratorate, after reviewing the cases transferred from the supervisory authority, believe that additional verification is necessary, they shall return them to the supervisory authority for additional investigation. The case may be supplemented by investigations if there is a case for non-prosecution stipulated by the Criminal Procedure Law. The decision of non-prosecution shall be made according to law upon the approval of the people's procuratorate at the next higher level. ${ }^{32}$ When the supervisory authority collects, fixes, reviews, and applies evidence, it should be consistent with the requirements and standards of evidence for criminal trials. ${ }^{33}$

\section{Clarification of the legal responsibility of the supervisory authority and its staff}

If the supervisory authority and its staff members violate any of the nine types of behaviors, such as the occurrence of security accident or the concealment, failure to report, improper disposal, improper handling, etc., the responsible persons shall be dealt with according to the law. ${ }^{34}$ The Supervision Law also provides: Where any supervisory organization or any of its functionaries infringes upon the lawful rights and interests of any citizen; or legal person or any other organization in the exercise of functions and powers that causes any damage, state compensation shall 
be made in accordance with the law. ${ }^{35}$

\section{Basic Characteristics of the Supervision LaW}

The purpose of the Supervision Law is to fix the centralized and unified leadership mechanism of the Chinese Communist Party on anti-corruption work through national laws; to establish a centralized, unified, authoritative and efficient national supervisory organization; and to work together with the Communist Party's disciplinary inspection authority to implement the party.

The internal supervision and state supervision and the party's disciplinary inspection and state supervision are organically unified; the ability and level of anti-corruption use of the law and the system are further enhanced; constant deterrence is strengthened; incorruptible control system is firmly in place; and the self-consciousness that cannot be avoided in corruption is enhanced. Compared with the previous monitoring laws in China, the characteristics of China's monitoring laws mainly focus on the inspection system of disciplinary inspections, the responsibilities and tasks of disciplinary inspections, the inspection and investigation measures of disciplinary inspections, and the characteristics of the Supervision Law. ${ }^{36}$

\section{A. New Changes in the Disciplinary Inspection System:}

\section{Centralized, Authoritative and Efficient}

Article 2 of the Supervision Law stipulates on a clear-cut basis the insistence and strengthening of the CPC's centralized and unified leadership on anti-corruption work. This will help the party committees at all levels be more confident and lawful in leading the Commission to conduct anti-corruption laws in accordance with the law. While waiting for work, it took up the political responsibilities of administering the party in a strict and governing state of affairs according to law. This is a different law that, following the amendment of the Chinese Constitution, emphasizes the thinking of Xi Jinping's leadership era. It also insists that the leadership of the Communist Party be included as a guiding ideology. ${ }^{37}$

According to the Supervisory Law, the Supervisory Commission is a specialized agency that is exercised by the People's Congress to carry out the functions of 
national supervision. It is accountable to the People's Congress and supervised by the National People's Congress. It strengthens the supervisory function of the National People's Congress as the organization of state power and broadens the people's supervision power. This approach embodies a people-centered concept. According to the CPC Central Committee's plan to deepen the reform of the national supervisory system, simultaneously, the National Supervision Commission and the Central Commission for Discipline Inspection will initially co-handle the work. They must first directly accept the leadership and supervision of the Party Central Committee and submit it to the Committee. Report work must be accountable to the Party Central Committee. This system is unique in the world. Such centralized, unified, authoritative and highly effective anti-corruption system with Chinese characteristics is embodied in the following aspects:

\section{Leadership System}

Under the direct leadership of the Party Committee, the Supervisory Committee is fully responsible for the Party Central Committee or the Local Party Committee; exercises supervision power on behalf of the Party and the State; and monitors the full coverage of all public officials implementing public power. It is neither an administrative agency nor a judicial agency to achieve the Party's leadership over the country's supervision, but a political institution that realizes the selfmonitoring of the Party and the State. ${ }^{38}$

The Supervisory Committee and the discipline inspection commission jointly manage the office and implement a set of working mechanisms; represent the two agencies; and serve to provide discipline inspection and supervision. They are both disciplinary organizations and law enforcement agencies which organically enforce the ruling party and the state law enforcement agencies. Through collaborative efforts, China has integrated the older decentralized administrative supervision, corruption prevention, and anti-corruption forces of the procuratorial agencies to achieve a centralized and unified leadership system, resources, strength, and means of anti-corruption work. The leadership system is highly consistent. ${ }^{39}$

The Supervisory Commission is an anti-corruption organization with Chinese characteristics. It is both a party organization and a state institution. Its supervisory power exercised by the law is no longer a simple superposition of anti-corruption, 
administrative supervision, and corruption prevention functions but is directly led by the Party. Next, on behalf of the party and the state, it not only investigates the illegal acts committed by all people who exercise public power, but also investigates their official crimes. Its functional jurisdiction is clearly distinct from that of the judicial and law enforcement agencies. ${ }^{40}$

When exercising jurisdiction, the Supervisory Commission shall report to the Party Committee at the same level for important matters. The National Supervision Commission shall lead the work of the local supervisory committees at various levels. The superior Supervisory Committee shall lead the work of the lower-level supervisory committees and the local supervisory committees at various levels for which the committee is responsible. Party committees at all levels represent the most direct and effective supervision of the leadership of the supervisory committee. . $^{41}$

For establishing the organization, the Supervisory Committee created by the National People's Congress should be responsible to the people's congresses and their standing committees and accept their supervision. It is in line with the people's government, the people's courts, and the people's procuratorates, forming the "one government, one committee, one court and one procuratorate" state power structure. The Supervisory Committee independently exercises the power of supervision according to law and is not interfered with by administrative agencies, social organizations and individuals. ${ }^{42}$

\section{B. The New Requirements of the Supervisory Committee's Duties and Tasks: "Two Rulers" and "Dual Duties"}

\section{Disciplinary Inspection Commission}

The Communist Party of China stipulates that the Disciplinary Inspection Commission is the party's internal supervision agency that performs the duties of supervision, discipline, and accountability in accordance with party rules and party discipline. ${ }^{43}$ The Party organizes and completes the maintenance of the party's statutes and other party rules and that checks the party's line. ${ }^{44}$ At the same time, the Disciplinary Inspection Commission assists the Party committee to promote the three main tasks comprehensively; strictly manage the party; strengthen party style construction; and organize and coordinate anti-corruption work. The 
Supervision Law stipulates that the Supervisory Commission has a particular duty organization to exercise the supervisory function of the state. It performs the "three duties of supervision, investigation and disposal" ${ }^{14}$ in accordance with the laws and regulations of the constitution and organizes the supervision of all public officials exercising public power in accordance with the Supervision Law, the investigation of illegal and duty crime, and the construction of a clean government and anticorruption. The main task is focused on corruption, which is the safeguarding of the dignity of the constitution and the law. ${ }^{46}$

Under this system, the Disciplinary Inspection Commission and the Supervision Commission jointly work and perform supervision and discipline accountability, supervise the investigation and disposition of "double responsibilities." Both apply the party constitution discipline and constitutional laws and "two regulations." Discipline inspection and supervision organizations must not only review violations of disciplines, but also enforce the law to investigate the problem of job violations and duty crime. They must consider both the factors of discipline and the content of the law, relying on discipline inspection, expansion supervision and judicial convergence.

\section{Coordinating "Two Rulers"}

The rule of discipline stipulated by the party constitution is to strengthen the supervision within the party; adhere to the strict discipline in law and discipline before law; use discipline to control party members and cadres; and maintain the advanced nature of the party. The "rules of the law" stipulated in the constitution, the Provisions Law and related laws and regulations are designed to supervise the public officials who do not meet the party's supervision or who do not apply the discipline of the executive party. Their primary purpose is to put public power under the control of the system.

\section{Implementing "Dual Duties"}

The Discipline Inspection Committee and the Supervisory Committee would overlap. Eighty percent of the civil servants and more than ninety-five percent of the leading cadres in the country are party members ${ }^{47}$ and there are intersections in service, both in the Discipline Inspection Committee and the Supervisory Committee. At the same time, the Supervision Law keeps the "good party 
members" in the 'prisoner' clear zone, while the Supervision Law controls the broad field between "good public servants" and 'prisoners' and prevents the small mistakes of party members and public officials from developing into catastrophes and prevents good people from becoming bad or corrupted. Ultimately, the law ensures that the power granted by the people is not abused.

\section{New Changes in Investigative Measures of the Supervisory Committee: Using Lien to Replace "Two Regulations (双规)"}

While the Supervision Law clarifies the three major duties of supervision, investigation, and disposal of the supervisory organizations, it stipulates that the supervisory organizations may exercise their own interviews, interrogations, inquiries, freezes, recalls, seals, seizures, searches, inquests, inspections; the 12 specific investigation measures, such as appraisal and retention, as well as three other measures that require strict approval procedures; technical investigations that require other agencies' assistance in their completion; and overnight passes and restrictions on exit. ${ }^{49}$ As a key measure of the authority of the supervisory authority, the indwelling is the only measure among the 12 investigation measures that limits the freedom of a person, replacing the "two regulations" with a lien; realizing the combination of party rules and state law; and trying to solve the problem of the rule of law and the standardization of anti-corruption investigation measures. Lien measures are both a tool for combatting corruption and a doubleedged sword. Improper use can also hurt innocent people and infringe human rights. Therefore, the Supervision Law has refined the application conditions, approval procedures and the rights protection of a lien. ${ }^{50}$

\section{The specific conditions for the strict application of the lien}

Where the person under investigation is suspected of corruption, bribery, neglect of duty, malfeasance in office, or any other serious duty-related violation or dutyrelated crime, and the supervisory organization has obtained some facts and evidence on the violation or crime but needs to conduct further investigations into important issues, after examination and approval by the supervisory organization in accordance with the law, the person may be detained at a specific place under any of the following circumstances: 1) The circumstances of the case in which the person is involved are major or complicated; 2) The person may escape or commit 
suicide; and/or 3) The person may make a false confession in collusion or forge, conceal or destroy evidence; and 4) The person may commit any other conduct that obstructs investigation. The supervisory organization may, in accordance with the provision of the preceding paragraph, detain any person who is suspected of giving bribes or committing any dual duty-related crime. The setup, management and supervision of detention places shall be regulated by the pertinent provisions of the state. ${ }^{51}$

\section{A strictly retained approval process}

The adoption of a detention measure by a supervisory organization shall be approved upon collective research by leaders of the supervisory organization. The adoption of a detention measure by a supervisory organization at or below the level of a district city shall be reported to the supervisory organization at the immediate higher level for approval. The provincial supervisory organization that decides to take the detention measure shall report it to the National Supervisory Commission for retardation. ${ }^{52}$

\section{Time limits for a strict lien}

The detention time shall not exceed 3 months. Special circumstances may be extended once, but the extensive time shall not exceed 3 months, and the report shall be submitted to the supervisory organization at the next higher level for approval. ${ }^{53}$ That is, the duration of the lien must not exceed 6 months, which can be compared with the time limit of China's Criminal Procedure Law for the investigation and detention of up to 7 months and maximum 20 months. The definite and strict detention period helps protect the lawful rights and interests of the detained persons.

\section{Procedural Law and Organizational Law}

The Supervision Law stipulates the organization and functions of the Supervisory Committee, as well as the specific procedures for monitoring work. In Chapter II (Supervisory Organizations and Their Duties), the Supervision Law stipulates that "the State Supervisory Committee is formed by the National People's Congress and is responsible for national supervision." "The State Supervisory Committee consists of the director, the deputy director and the members of the committee, 
and the director is the National People's Representative. The deputy director and members of the committee shall be nominated and removed from the Standing Committee of the National People's Congress by the deputy director and member of the National People's Congress." The local level Supervisory Committee is formed by the people's congress at the local level and is responsible for the supervisory work in the Administrative Region. ${ }^{55}$

The Supervision Law is the organization law of supervisory work, which specifically stipulates the nature of the supervisory organizations, the positioning of the supervisory organizations, how to elect the director, the relationship with other judicial law enforcement agencies, and who is responsible for whom being supervised. This content belongs to the category of organization law. At the same time, the Supervision Law confirms the supervisory authority and supervision procedures of the supervisory organizations through a series of provisions. It provides: "The supervisory organizations should carry out the work strictly in accordance with the procedure and establish the working mechanism of dealing with, investigating, and hearing each other's coordination and mutual restrictions." $" 56$

The Supervision Law is to govern the organization of supervisory work. It specifies the nature of supervisory organs, the orientation of supervisory organs, how to elect directors, the relationship with other judicial legislative and law enforcement organs, and who is responsible and who is supervised. These contents belong to the scope of organizational law. All of this content belongs to the category of procedural law. ${ }^{57}$ The Supervision Law is both an organization and procedural law. It lays down the organization and procedures of the supervisory organization at the same time.

\section{Disputes and Tasks of the Supervision Law}

The concept and model of the rule of law in China simultaneously absorb the concepts and systems of a legislature ruled by law, the rule of law and the administration of the rule of law. Those build a multi-integrated political law to govern the country, which is a mixed legal model based on interactive systems of political parties and countries. ${ }^{59}$ The Supervision Law is the first direct expression 
of the "political party's rule of law." ${ }^{, 60}$ This pattern of governing power also raises the issue of "who will supervise the higher power or supreme power" and how to "realize human rights protection."

\section{A. Who Will Oversee the Supervision Committee?}

Should the Disciplinary Inspection Commission of the Communist Party of China and the state supervisory commission be a strong authority of the office of the state? How should then it strengthen the supervision and restriction of the new institutions? In the beginning of the legislation of the Supervision Law, "who came to supervise the supervision committee" will be a critical issue that could not be bypassed.

\section{Supervision of the Party Committee}

The Supervision Law stipulates that "the leadership of the Communist Party of China over the national supervisory work shall be adhered to Marxism-Leninism, Mao Zedong Thought, Deng Xiaoping Theory, the Theory of Three Represents, the Scientific Outlook on Development, and Xi Jinping Thought on Socialism with Chinese Characteristics for a New Era..." ${ }^{, 61}$ The leadership itself includes education and supervision. Under the leadership of the party committees at the same level, the Supervisory Committee, under the leadership of the Party committee at the same level, supervises all Party members and officials exercising public power and public officials and conducts the investigation and disposal of illegal and illegal crimes. This is a major embodiment of adhering to the party's principle of managing cadres and strengthening the overall leadership of the party. The principle of party management of cadres is reflected not only in the cultivation, promotion and use of cadres, but also in the education, management and supervision of cadres that is in compliance with law and discipline. The Supervision Law takes the supervision of the party committee as the primary supervision and leads the party's leadership throughout the whole process of supervision in all aspects. ${ }^{62}$

\section{Supervision of the People's Congress}

According to the relevant provisions of the Supervision Law, the NPC's supervision of the Supervisory Committee is rich and varied in form. Regarding the appointment and removal of personnel, the directors of the national and local supervisory 
committees are chosen by the national and local people's congresses. The deputy directors and members of the committee are nominated and removed from the Standing Committee of the national and local people's congresses at the national and local levels. ${ }^{63}$

According to the particular nature of the inspection and supervision work and the confidentiality of the cases, the supervisory organizations are not suitable for reporting the work directly to the people's congress, but they make reports to the standing committee of the people's congress at all levels and request the consideration of a special work report of the supervisory organizations of the local people's congress and accept the law enforcement examination organized by the standing committee of the people's congress. In addition, the people's formation is replaced by the people's congress. The representatives of the general assembly or the standing committee may ask or inquire about the pertinent issues in the supervision work in accordance with legal procedures when the NPC and its Standing Committee meetings are held. ${ }^{64}$

\section{Judicial supervision and supervision of law enforcement}

According to the applicable provisions of the Supervision Law, anti-corruption work is linked with checks and balances. The decisions are made by the supervisory organizations after the investigation is subject to the supervision of the judiciary. Some investigative measures also require the assistance of other law enforcement agencies. The supervisory organization is in charge of the investigation of a corruption case and the review of the investigation and prosecution of the alleged job-related crime by the procuratorial agency. After a review by the supervisory authority, if the procuratorial authority considers that a crime has been ascertained and that the evidence is accurate and sufficient, the investigation shall be pursued according to law. If criminal liability is deemed necessary, a decision on the prosecution shall be made; if it is deemed necessary to make a supplementary verification, the case shall be returned to the supervisory organization for supplementary investigation and, if necessary, it may supplement the investigation with one of its own; if it is considered that there is a case for non-prosecution as prescribed by the Criminal Procedure Law, the case shall be handled by the people's procuratorate at the next higher level. This institutionally forms a working mechanism for investigation by the supervisory commission, the prosecutor's 
office, and court trial. ${ }^{65}$

\section{Other external supervision}

In the process of controlling the operation of power, external supervision is essential. The Supervision Law establishes a system of complaints and accountability for misconduct of the supervisory organizations and their staff. It clearly stipulates that under specific circumstances, the investigated party and his or her close relatives have the right to appeal against the relevant acts of the supervisory organizations and their staff if the supervisory organizations and their staff do not perform their duties and investigations in accordance with laws and regulations. If there is harm to the lawful rights and interests of the investigated persons, those can be supervised by way of accusation, complaint and so on. ${ }^{66}$ At the same time, it also stipulates that supervisory organizations should publicize information on supervisory work according to law and accept democratic supervision, social supervision and supervision by public opinion. ${ }^{67}$

\section{Strict self-monitoring}

In addition to the above comprehensive external supervision, the Supervision Law highlights a very strict self-supervision. Chapter 7 of the Supervision Law provides the "supervision of supervisory organizations and inspectors." Also, the additional chapters also stipulate the perspectives of strengthening internal self-supervision. The Supervision Law clearly stipulates "the system of filing reports on inquiries, cases of interrogation, and intercession of intercession,",68 the avoidance of supervisors, ${ }^{69}$ the management of deprivation, the dismissal of supervisors, the restrictions on the practice of retiring from employment, and the accountability for major errors in the disposal of cases. ${ }^{70}$ The supervision power has been restricted by various procedures and measures, and internal supervision has been strengthened with more stringent standards and measures.

\section{The clear legal responsibility of supervisory authorities and their staff}

Chapter 8 of the Supervision Law stipulates that the supervisory authority and its staff members are responsible for any of nine types of violations, such as the occurrence of a security accident in the case of a violation of regulations, concealment, failure to report, inaccurate reporting, or improper handling after a 
security incident occurs. Responsible leaders and directly responsible personnel are given legitimate treatment. ${ }^{71}$ At the same time, the Supervision Law also stipulates that the supervisory authority and its staff members exercise their power and infringe upon the legitimate rights and interests of citizens, legal persons and other organizations. If damages are caused, they shall be compensated by the State according to law. ${ }^{72}$ Through the abovementioned comprehensive external supervision and strict internal oversight mechanisms and legal responsibilities, the authority of the supervisory authority is placed under the control the system so that the supervisory authority and its staff always perform their duties under strict supervision and control to prevent the abuse of power.

\section{B. How to Protect Human Rights?}

The supervision work of the state shall strictly comply with the PRC Constitution and laws, take facts as the basis and laws as the criterion, equally apply laws to all parties, and guarantee the parties' lawful rights and interests. Equal consideration shall be paid to power and responsibility. ${ }^{73}$ Article 5 of the Supervision Law stipulates the guiding ideology and guiding principles that should be applied in inspection work, but there is no provision for "respecting and safeguarding human rights." The PRC Constitution stipulates that "the state respects and safeguards human rights." state organization exercising its functions and powers should follow the principles of respecting and guaranteeing human rights stipulated under the constitution. The Supervisory Committee is no exception. As far as the Supervisory Committee is concerned, it needs more emphasis on the respect and protection of human rights for the following the two characteristics.

First, in accordance with the provision of the Supervision Law, the Supervisory Committee has overseen an extensive number of public officials exercising public power. The number of objects supervised by the Supervisory Committee is quite large. After the pilot reform in Beijing, Shanxi and Zhejiang, Beijing's monitoring target reached 997,000 people (787,000 more than before the reform); 1,315,000 in Shanxi Province (530,000 more than before the reform); and 701,000 in Zhejiang Province $\left(318,000\right.$ more than before the reform) ${ }^{75}$ With the implementation of the pilot reform of the supervisory system in the whole country, the monitoring target has become the public servant who exercises public power over all the country's "eating of financial meals." ${ }^{76}$ After these people become the investigators, the 
supervisory organizations should protect their legitimate rights as citizens.

Second, the functions of the Supervisory Committee have been extended to the pursuit of duty crime. Therefore, the Supervisory Committee has been given a series of powers and some strict investigative measures, such as interrogation, search, seizure, lien, technical investigation and other investigation measures, ${ }^{77}$ to ensure effective anti-corruption work. Under such circumstances, the power of the Supervisory Committee must not be restricted under the principle of human rights protection. The 2012 amended Criminal Procedural Law added the provision of "respect for and guarantee of human rights," whole criminal procedures. In the reform of the supervisory system, the power to investigate duty crime by the procuratorial organization has been transferred to the investigative power of the Supervisory Committee. Here, the one-sided thinking of "turning power only and not transferring rights" should be avoided.

Third, the investigation of job-related crimes by the Supervisory Committee should allow lawyers to intervene. The Supervision Law does not clarify the problem of lawyers' involvement in the investigation of job-related crimes. This involves major questions on human rights protection as follows. 1) In accordance with the Supervision Law, the supervisory organizations enjoy a variety of measures, such as interrogation, inquiry, freezing, search, lien, technical investigation and so on. Some measures are fairly severe. According to the Supervision Law, detention time is usually three months, which can be increased to 6 months if necessary. ${ }^{79}$ Although the lien is different from the term arrest, it is essentially a compulsory measure to deprive citizens of personal freedom for a long time. When conducting an investigation for any suspected major duty-related crime such as corruption and bribery, the supervisory organization may perform strict approval formalities to take technical investigation measures and assign them to the relevant organization for execution according to relevant provisions. ${ }^{80}$ The implementation of the technical investigation measures involves the private and public interests of citizens; thereby easily infringing on the personal and property rights of citizens. Under such circumstances, it is important to abide by the procedural rule of law allowing lawyers to intervene. This is a basic requirement to ensure procedural justice and civil rights.

2) In 1996, China amended the Criminal Procedure Law to allow the lawyer's intervention in advance to the investigation stage. In the 2012 amendment, the 
Criminal Procedural Law expanded and effectively guaranteed the litigation rights of defense lawyers in criminal proceedings. ${ }^{81}$ Even if a criminal accused is suspected of state security, terrorist activities and particularly serious bribery crime, the accused still has the right to hire a lawyer for legal defense. ${ }^{82}$ In reforming the supervision system, fundamental human rights should not be ignored. The Supervision Law should be compared with the Criminal Procedure Law, allowing lawyers to be involved from the beginning or at the latest after the indwelling. Otherwise, this is a substantial retrogression in the protection of rights. ${ }^{83}$

In general, lawyers are generally allowed to intervene if persons are deprived of personal freedom or their property is searched. This is the international norm: "No one shall be subjected to enforced disappearance." ${ }^{84}$ In addition, the detainee shall be entitled to defend himself or herself or to be defended by law in accordance with the law. ${ }^{85}$

\section{Conclusion}

The Supervision Law is the only anti-corruption legislation to govern China's anti-corruption work. The purpose of the Supervision Law is to make up for the inadequacy of China's current supervisory system and institutionalize anticorruption. It is a combination of the party rules and national laws. For example, 'dual regulations' in the party rules and the "liberties" in the national law are the 'detention' in the judicial process as well as the direct embodiment and beginning of party rule.

The power exercised by the Supervisory Committee is not within the constitutional jurisdiction. The 2018 amendment of the PRC Constitution established new state power structure that the government should exercise executive power; the courts and the procuratorate should implement judicial power; and the Supervisory Committee should supervise the power. All these powers, however, come from the National People's Congress. ${ }^{86}$ This power structure is completely different from the separation of the three powers in western countries. It does not control power through checks and balances for the realization of civil rights. That is, supervision of power corruption is mainly achieved through the upper level of power, which inevitably presents the dilemma of "who will supervise the Supervisory 
Committee or the higher power."

The Supervision Law stipulates that 'upholding' of up to six months may not explicitly provide for "places of detention" and "lawyer rights." Nor does it effectively link up with Chinese criminal laws, constitutions, and other regulations. This raises concerns about the "human rights issues" and "procedural issues" in the Supervision Law. On November 7, 2017, the National People's Congress released a draft of the Supervisory Law for the first time and openly solicited opinions from the public. Professor Chen Ruihua of Peking University, pointing out seven major issues in the draft of the Supervision Law, ${ }^{87}$ asked: "Will it bring about progress in the rule of law or will it lead to a retrogression in the rule of law?"

In general, the Supervision Law is not only tantamount to important changes in China's anti-corruption legislation, but also a sign of great changes in the structure of China's state power. That is a change in China's way of conducting governance, which will have a profound influence on the future political and legal aspects of China.

\section{REFERENCES}

1. Yanhong Liu, Theory and Practice in the implementation of the Supervision Law [《监察法》 贯彻实施中的理论与实践], 5 J. EAst China U. Politics \& L. [华东政法大学学报] 3 (2006).

2. Id.

3. SLPRC arts. 7-13\& 15.

4. Juntao Liu, Beijing, Shanxi, Zhejiang will carry out pilot reform of the national supervisory system [北京山西浙江将开展国家监察体制改革试点], PEOPLE's NETWORK [人民网], available at http://politics.people.com.cn/n1/2016/1107/c1001-28842606.html.

5. Supervision Law of the People's Republic of China [中华人民共和国监察法], available at http://www.ccdi.gov.cn/fgk/law_display/6340 or https://baijiahao.baidu.com/s?id=159554 $0464117524378 \& w f r=$ spider\&for $=$ pc.

6. Jianguo Li, Explanation of Supervision Law of the People's Republic of China [关于中华人 民共和国监察法(草案) 的说明], PEOPLE'S NETwORK [人民网], available at http://cpc.people. com.cn/n1/2018/0314/c64094-29866183.html.

7. SLPRC art. 2.

8. Id. art. 4.

9. Id. art. 5 . 
10. Id. art. 8 .

11. Id. art. 9 .

12. Id. art. 11.

13. Id. art. 11(1).

14. Id. art. 11(2).

15. Id. art. 11(3).

16. Id. art. 11(3).

17. Id. art. 11(3).

18. Id. art. 11(3).

19. Id. art. 11(3).

20. Id. art. 11(3).

21. Id. art. 11(3).

22. Id. arts. 19-21 \& 23-27.

23. Id. art. 22.

24. Id. arts. 28-30.

25. Id. arts. 35-42 \& 46.

26. Id. art. 43.

27. Id.

28. Id. art. 44.

29. Id. art. 53.

30. Id. arts. 57-61.

31. Id. art. 54.

32. Id. art. 47(2-3).

33. Id. art. 33 (2).

34. Id. art. 65.

35. Id. art. 67.

36. Liping Liang, Formation, Characteristics and Development of Anti-Corruption Road with Chinese Characteristics [中国特色反腐倡廉道路的形成、特征与发展], 1 J. THEORETICAL EXPLORATION [理论探索] 10-2 (2012).

37. SLPRC art. 2.

38. Id. arts. 2-3.

39. The Central Committee of the Communist Party of China, Program for Deepening the Reform of Party and State Institutions [中共中央印发《深化党和国家机构改革方案》], XINHUANET, Mar.

21, 2018, available at http://www.gov.cn/zhengce/2018-03/21/content_5276191.htm\#1. 40. Id.

41. Id.

42. P.R.C. Const. art. 37.

43. Supra note 39.

44. Zhexi Yu, How does the Commission for Discipline Inspection act as the party responsible 
for supervision within the party? Strictly supervise and discipline accountability with the party constitution and party discipline as the ruler [纪委如何履行党内监督专责机关的 职责? 以党章党规党纪为尺子严格监督执纪问责], 21 CHINA's DisCIPLINE INSPECTION \& SUPERVISION [中国纪检监察] 51-2 (2016).

45. SLPRC arts. 18-34.

46. Id. art. 3.

47. Yu, supra note 34.

48. The direct basis for the "two regulations (双规)" is the second paragraph of Article 28 of the "Regulations on the Inspection of Cases of the Communist Party of China's Discipline Inspection Organs," which was implemented on May 1, 1994: "Require relevant personnel to refer to the case at the specified time and place. The problem is explained." It is characterized by restrictions on personal freedom before the judicial process, and the object of application is the Communist Party. For non-communist members, it is known as “two appointments (双指)."

49. SLPRC arts. 18-34.

50. Id. art. 22.

51. Id. art. 22.

52. Id. art. 43.

53. Id. art. 33 .

54. Id. art. 8 .

55. Id. arts. 7-14.

56. Id. art. 36 .

57. Id. arts. 35-4.

58. Linzong Lan \& Juan Li, Understand these seven key points, you will understand the supervision law [理解好这7个关键点, 你就读懂了监察法], XINHUANET, available at http:// www.xinhuanet.com/2018-03/22/c_1122575014.htm.

59. Shigong Qiang, Jurisprudential thinking on the relationship between party law and national law [从行政法治国到政党法治国-党法和国法关系的法理学思考], 3 CHINESE LEGAL REv. [中国法律评论] 35-41 (2016).

60. Id. at 36 .

61. SLPRC art. 2.

62. Id.

63. Id. arts. 8-9.

64. Id.

65. Id. arts. 45-47.

66. Id. art. 60 .

67. Id. arts. $54 \& 56$.

68. Id. art. 57.

69. Id. art. 58 . 
70. Id. art. 59.

71. Id. art. 65 .

72. Id. arts. 66-67.

73. Id. art. 5.

74. P.R.C. Const. art. 33.

75. Active exploration and practice, forming valuable experience, and achieving effective results in the reform of state supervision system [积极探索实践形成宝贵经验 国家监察体制 改革试点取得实效-国家监察体制改革试点工作综述], XINHUANET, Nov. 5, 2017, available at http://www.xinhuanet.com/2017-11/05/c_1121908387.htm.

76. SLPRC art. 15.

77. Id. arts. 18-34.

78. P.R.C. Criminal Procedure Law art. 2.

79. SLPRC art. 43.

80. Id. art. 28.

81. P.R.C. Criminal Procedure Law art. 96.

82. Id. art. 33. It states: The criminal suspect has the right to appoint a defender from the date of the first interrogation by the investigating agency or the adoption of compulsory measures; during the investigation, only the lawyer can be entrusted as a defender. The person has the right to appoint a defender at any time.

83. Guangzhong Chen \& Dan Jiang, Eight-point amendments to the Supervisory Law [关 于《监察法 (草案)》的八点修改意见], 6 CoMP. MEthoD RES. [比较法研究] 164-73(2017).

84. International Convention for the Protection of all Persons from Enforced Disappearance, art. 1.

85. The 11th principle of the United Nations Principles for the Protection of All Persons under Any Form of Detention or Imprisonment.

86. P.R.C. Const. art. 37.

87. Ruihua Chen, The seven problems in the draft Supervision Law [《监察法》草案存在的七个 问题], Nov. 8, 2017, available at http://wemedia.ifeng.com/36271260/wemedia.shtml.

88. Id. 